\title{
Pyroclastic Flow from Soufrière Hills Volcano, Montserrat: Solid Block Model
}

\author{
Irina Nikolkina ${ }^{1,2,3}$, Narcisse Zahibo $^{1}$, Tatiana Talipova ${ }^{3}$, Efim Pelinovsky ${ }^{1,2,3}$ \\ ${ }^{1}$ Physics Department, University of the French West Indies and Guiana, Pointe-à-Pitre, Guadeloupe, France \\ ${ }^{2}$ Department of Applied Mathematics, Nizhny Novgorod State Technical University, Nizhny Novgorod, Russia \\ ${ }^{3}$ Department of Nonlinear Geophysical Processes, Institute of Applied Physics, Nizhny Novgorod, Russia \\ E-mail: irina.nikolkina@gmail.com \\ Received March 5, 2011; revised June 7, 2011; accepted July 11, 2011
}

\begin{abstract}
The solid block model is applied to describe the motion of the pyroclastic flow under the joint action of gravity and Coulomb friction. Special attention is paid to characteristics of the pyroclastic flow generated by Montserrat volcano in likely directions. The critical friction angle of the flow propagation is evaluated empirically. Characteristic parameters of the pyroclastic flow (travel time and impact velocity) are well approximated by linear regressions. Proposed estimations of the parameters of pyroclastic flow are useful for the rough and express evaluation of its characteristics.
\end{abstract}

Keywords: Landslide Dynamics, Solid Block Model, Soufrière Hills Volcano

\section{Introduction}

The Soufrière Hills Volcano, Montserrat situated in the Caribbean (Figure 1) has been erupted since 1995. The activity of volcano has been carefully studied by [1-6]. Since 1995 three events have triggered the tsunami waves in December 1997 [7,8], July 2003 [9], May 2006 $[10,11]$.

Various mathematical models were developed to describe the motion of the avalanche and the landslide dynamics [12-18]. The solid block model has been widely used [19-22] for rough estimations of landslide characteristics. Real and potential explosions of the Soufriere Hills Volcano were modeled using different models, see [7, 23-25].

In this paper special attention is paid to the characteristics of the pyroclastic flow generated by the Soufriere Hills Volcano. The travel time and the impact velocity of the pyroclastic flow are computed applying the solid block model in order to estimate potential debris avalanche hazard associated with the eruption of the Soufrière Hills Volcano.

\section{Mathematical Model}

According to the solid block approach, the pyroclastic flow is modeled as a solid block of a mass $m$ sliding down a titled plane with a constant slope angle $\alpha$, under the action of gravity $m g$, where $g$ is acceleration of gravity, the friction $F$, and the normal force $N$. Let us consider a two-dimensional coordinate system $X Z$, Figure 2. The normal force $N$ equals the component of the gravitational force:

$$
N=m g \cos \alpha
$$

The simple Coulomb friction law applied here is based on a constant basal friction angle $\delta$ that is an empirical property of the contacting materials:

$$
F=\mu m g \cos \alpha, \mu=\tan \delta .
$$

The motion equation along $x$-coordinate is given by the second Newton's law:

$$
\frac{\mathrm{d}^{2} x}{\mathrm{~d} t^{2}}=g \cos \alpha \sin \alpha-\mu g \cos ^{2} \alpha .
$$

If we have the complex path of the pyroclastic flow which consists of several approximately constant slopes and the constant friction, the Equation (3) transforms into the set of equations

$$
\frac{\mathrm{d}^{2} x_{i}(t)}{\mathrm{d} t^{2}}=g \Psi_{i}, \quad \text { where } \Psi_{i}=\cos \alpha_{i} \sin \alpha_{i}-\mu_{i} \cos ^{2} \alpha_{i},
$$

and $i$ is a number of the path. Previously, the equation of 


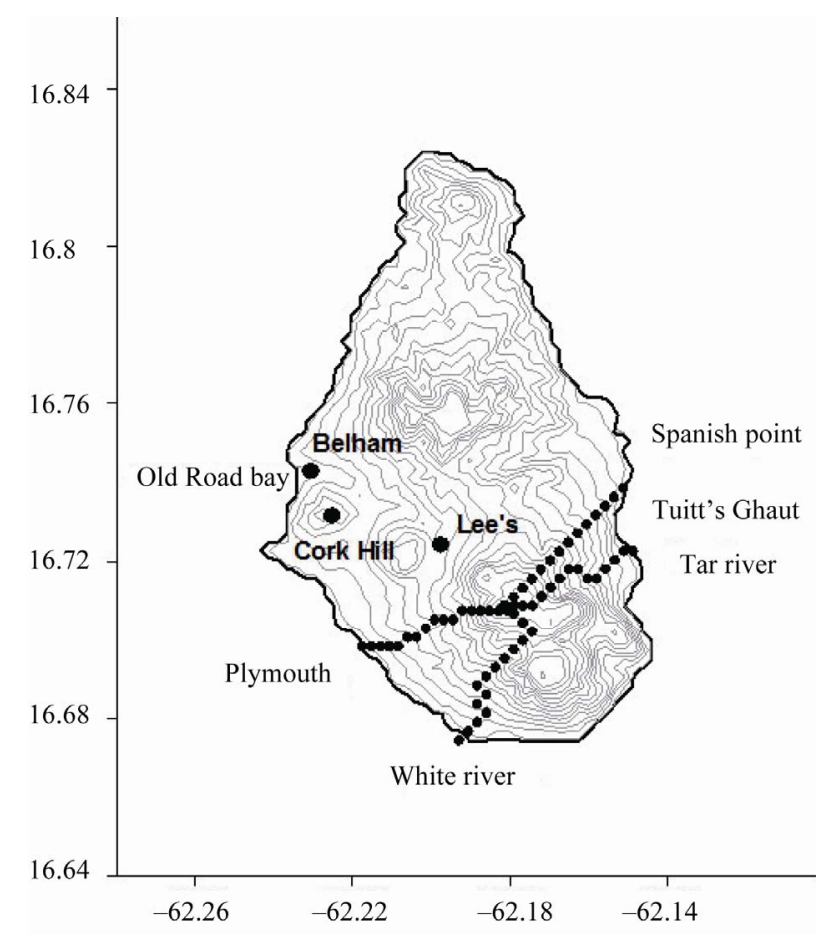

Figure 1. Montserrat Island, Lesser Antilles, Caribbean Sea.

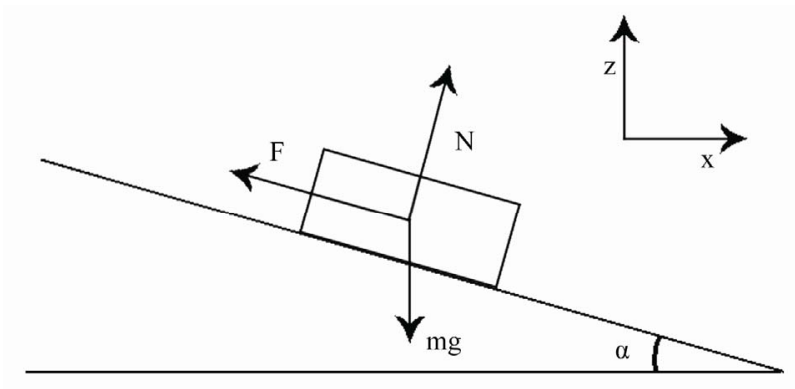

Figure 2. Model geometry: A block slides down a slope tilted $\alpha$ under the action of gravity force $m g$, friction $F$, and normal force $N$.

motion was solved numerically for paths of complex geometry for the snow-avalanche motion [26]. After integrating the Equation (4) we obtain the velocity of the pyroclastic flow in the end of the $i$-part:

$$
v_{i}=g \Psi_{i}\left(T_{i}-T_{i-1}\right)+v_{i-1},
$$

where $T_{i}$ is the travel time and $v_{i-1}$ is the initial velocity on the start point of the $i$-part. The travel time is determined after the second integration of the Eq.(4)

$$
T_{i}=T_{i-1}+\sqrt{\mathrm{B}_{i}^{2}+\frac{2 L_{i}}{g F_{i}}}-\mathrm{B}_{i}, \quad \mathrm{~B}_{i}=\frac{v_{i-1}}{g \Psi_{i}}, \quad L_{i}=x_{i}-x_{i-1} .
$$

In case $\tan \alpha_{i}-\mu_{i}>0$ the pyroclastic flow reaches the sea, otherwise the pyroclastic flow stops if the initial velocity is not too high

$$
v_{i-1}<\frac{\sqrt{2 g L_{i}\left(\mu_{i}-\tan \alpha_{i}\right)}}{\cos \alpha_{i}} .
$$

Of course, the Equation (3) can be easily integrated numerically for any mountain profile. In fact, all available digital maps have a resolution of several hundred meters, and the linear approximation of the profile is a natural spline. The approximation discussed here can be applied to study the dynamics of the pyroclastic flow if its horizontal scale of the pyroclastic flow is less than the length of each path.

Let us now apply this model to analyze the characteristics of the pyroclastic flow from the Soufrière Hills Volcano, Montserrat.

\section{Characteristics of Pyroclastic Flow at Sea Entry}

This simplified theoretical model is applied to calculate the parameters of the pyroclastic flow from the Soufrière Hills Volcano in directions of Tuitt's Ghaut, Plymouth, Tar River and White River valley, hereafter referred as likely directions.

To study the propagation of the pyroclastic flow, two parameters should be determined: Coulomb friction and initial velocity of the pyroclastic flow.

In fact, data of initial velocities of the pyroclastic flows from the Soufrière Hills Volcano is poorly documented. We can expect (see below) that the initial velocity has the same order as the mean velocity. Mean velocities of pyroclastic flows from the Soufrière Hills Volcano were measured earlier: $5 \mathrm{~m} / \mathrm{s}-30 \mathrm{~m} / \mathrm{s}$ in 1996-1997 [27,28], $15 \mathrm{~m} / \mathrm{s}$ in 2003 [2]. In fact, Calder et al. [29] suggested that velocity of dome-collapse flows was up to $10 \mathrm{~m} / \mathrm{s}-60 \mathrm{~m} / \mathrm{s}$. The simplified estimation of initial velocity can be done using the assumption that a dome collapses and falls as a free body in a crater achieving velocity $v_{0}=\sqrt{2 g h}$, where $h$ is a height of lava dome. Assuming that it varies from $50 \mathrm{~m}$ to $100 \mathrm{~m}$, the initial velocity attains $30 \mathrm{~m} / \mathrm{s}-40 \mathrm{~m} / \mathrm{s}$. These values argued with estimates by [29] are used in further calculations.

As for the basal friction angle, usually it is considered to be equal to $17^{\circ}-30^{\circ}$ for the sand-textured debris [24] and $20^{\circ}-40^{\circ}$ for the granular debris avalanche [30]. Previously the debris avalanche from Caribbean volcanoes was actively modeled [24,30,31] and appropriative basal friction angle was suggested to be rather small $\left(5^{\circ}<\delta<8^{\circ}\right.$ for Mt Pelée, Martinique and $13^{\circ}<\delta<35^{\circ}$ for the Soufrière Hills Volcano, Montserrat). Earlier Heinrich et al. [24] suggested that the best agreement between calculated and theoretical data was 
obtained when the small basal friction angle $13^{\circ}<\delta<15^{\circ}$ is used. Furthermore, the motion of real landslides is governed by low values of the friction angle [24-30]. Considering these studies, values $8^{\circ}-17^{\circ}$ are chosen to estimate the characteristics of the pyroclastic flow in the present study.

Below the pyroclastic flow from the Soufrière Hills Volcano is studied in likely directions.

\subsection{Tar River Direction}

According to results of the marine geophysical survey on the flanks of Montserrat, deposits are located $15 \mathrm{~km}$ offshore the Tar River valley [32]. During a period of heavy rainfall on 29 July 2001 the low volume pyroclastic flows in the Tar River Valley continued for five hours before intensifying into large pyroclastic flows with surges [2]. Totally, three large lava dome collapses occurred in the Tar River Valley between November 1999 and July 2003 [2]; in July 2003 the pyroclastic flows impacted the sea and produced tsunami [9]. Small pyroclastic flows also occurred in the Tar River Valley in November-December 2009 [33].

Different splines of the volcano profile in the Tar River direction are demonstrated in Figure 3. The original spline represents 3" resolution map presented in [34], Figure 3(a). Various splines are used in order to study the sensitivity of the results to the resolution, see Figures 3(b)-(d). First and second volcano profiles consist of 14 and 7 paths correspondingly, and a zone of an easy slope $\left(5^{\circ}-12^{\circ}\right)$ is clearly observed. The use of the small friction angle $\left(13^{\circ}-15^{\circ}\right)$ recommended previously by Heinrich et al. [24], and initial velocity of $30-40 \mathrm{~m} / \mathrm{s}$ leads to deceleration and stop of the pyroclastic flow in the area of the top. Then, a long-distance steep zone with a maximum slope angle of $34^{\circ}$ begins; and finally, a third easy zone $2000 \mathrm{~m}$ - $2250 \mathrm{~m}$ off the volcano peak is characterized by the moderate slope angle $\left(1^{\circ}-12^{\circ}\right)$. So, the first (original) and the second (approximated) profiles can be divided into three zones characterized by the different average slope angle, Figures 3(a) and (b).

The third profile (Figure 3(c)) is rather homogeneous in terms of the slope angle; it varies smoothly from $15^{\circ}$ to $5^{\circ}$. The last profile (Figure 3(d)) represents a linear approximation of the original one; the slope angle is equal to $14^{\circ}$. Calculations with the use of the initial velocity $(30 \mathrm{~m} / \mathrm{s}-40 \mathrm{~m} / \mathrm{s})$ and the moderate slope angle $\left(\alpha<17^{\circ}\right)$ show that neither third nor fourth profiles "obstruct" the propagation of the pyroclastic flow; and it reaches the sea.

Thus, results are sensitive to the resolution of the profile, and the use topographic maps of low resolution can lead to improper conclusions.

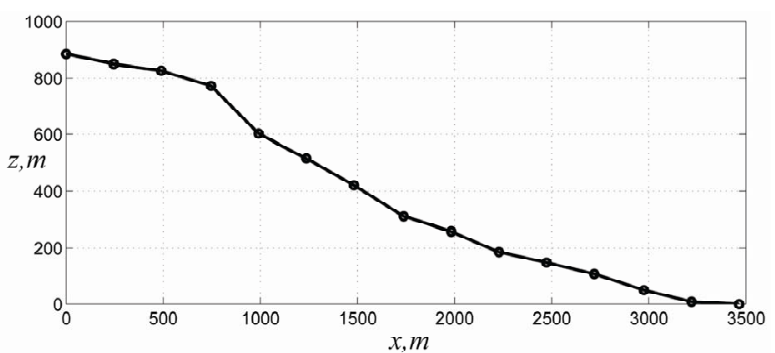

(a)

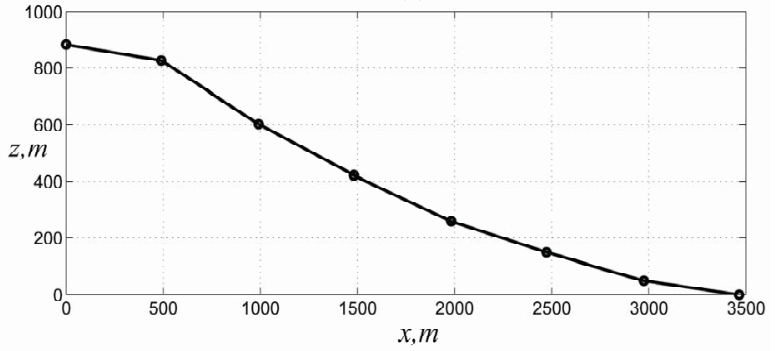

(b)

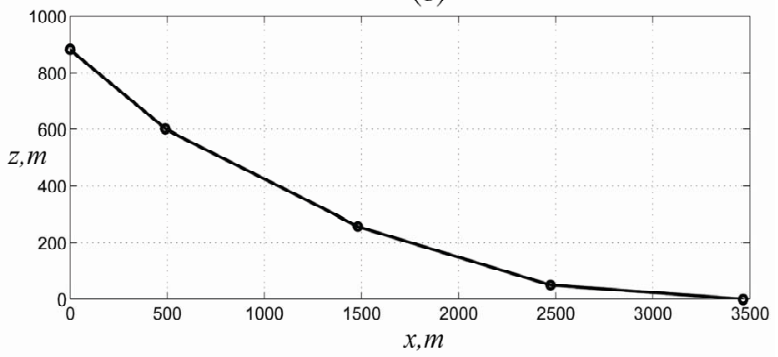

(c)

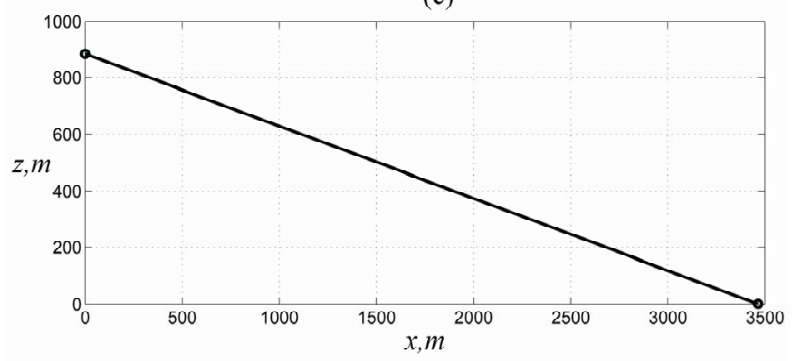

(d)

Figure 3. Profile of Tar River valley in different resolutions: original (a), small (b), moderate (c), linear approximation (d).

The use of small friction angle $\left(8^{\circ}-15^{\circ}\right)$ and the initial velocity of $40 \mathrm{~m} / \mathrm{s}$ permit us to observe some peculiarities of the pyroclastic flow: in terms of the spatial and temporal variation of the velocity, it is described rather fairly when the first and second profiles are used $(250 \mathrm{~m}$ and $500 \mathrm{~m}$ ); the effect of the easy slope that decelerate the pyroclastic flow, is observed $500 \mathrm{~m}-700 \mathrm{~m}$ from the volcano peak, Figure 4. Then, the velocity decreases slightly hundred meters off the shore.

As for the travel time, it does not exceed 2 minutes, Figure 4. The pyroclastic flow stops on the top of the volcano when the initial velocity of $30 \mathrm{~m} / \mathrm{s}-35 \mathrm{~m} / \mathrm{s}$ is 
used. A case of maximum initial velocity is specially studied here because it permits to estimate the minimum travel time that is important in terms of time alert. As mentioned, results are sensitive to the resolution of the profile, and the moderate $(250 \mathrm{~m}$ and $500 \mathrm{~m})$ and the original resolution $(250 \mathrm{~m})$ is used in order to obtain reasonable data.

Let us study the critical parameters of the pyroclastic flow for moderate resolutions $(250 \mathrm{~m}-500 \mathrm{~m})$. As discussed earlier, the pyroclastic flow stops when the moderate resolution is applied. The proposed range of unknown parameters (the initial velocity and the friction angle) is used to identify the "behavior" of the pyroclastic flow. The critical values of the friction angle vary from $12^{\circ}$ to $15.5^{\circ}$. The pyroclastic flow stops when the critical value is exceed (other conditions being equal). For example, the pyroclastic flow does not reach the sea when the initial velocity is $33 \mathrm{~m} / \mathrm{s}$ and friction angle exceeds $13^{\circ}$ in case of moderate resolution, see Figure 5(e). The critical friction angle is evaluated empirically from the performed calculations for the moderate resolution, and the linear regression has the following form:

$$
\delta_{C}=0.3 \cdot v_{\text {int }}+2.5, R=0.94,
$$
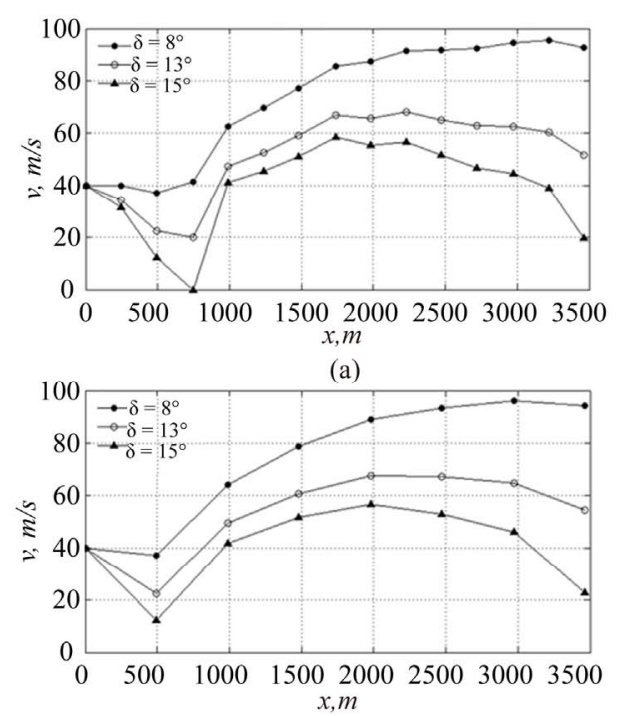

(c)

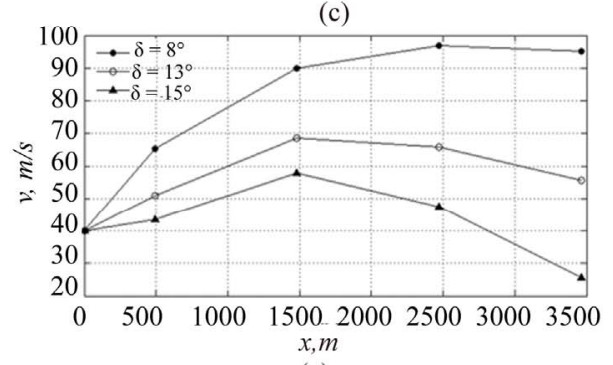

(e) where $v$ is in $\mathrm{m} / \mathrm{s}$, hereinafter $R$ is a coefficient of correlation.

Two parameters of the propagation of the pyroclastic flow (the travel time and the impact velocity) are specially studied for the original resolution. Calculations are produced for different initial velocity $(30 \mathrm{~m} / \mathrm{s}, 35 \mathrm{~m} / \mathrm{s}$ and $40 \mathrm{~m} / \mathrm{s}$ ), and a wide range of the friction angle $\left(8^{\circ}-17^{\circ}\right)$, Figure 5(i). In general, the travel time does not exceed 2 minutes. The travel time is can be approximated by the following equation:

$$
T_{\text {Tar River }}=5 \cdot \delta+13 \quad R=0.79
$$

where $T$ is in seconds, the friction angle $\delta$ is in degrees. In all cases the impact velocity does not exceed $100 \mathrm{~m} / \mathrm{s}$. A minor rise of the basal friction angle reduces significantly the velocity of the pyroclastic flow. For example in a case when the initial velocity is $40 \mathrm{~m} / \mathrm{s}$, the sought parameter decreases twice (from $80 \mathrm{~m} / \mathrm{s}$ to $40 \mathrm{~m} / \mathrm{s}$ ) while basal the friction angle increases from $10^{\circ}$ to $14^{\circ}$, Figure $5(\mathbf{m})$. The impact velocity $v$ can be fitted by

$$
v_{\text {Tar River }}=-10 \cdot \delta+175, \quad R=0.98,
$$

where $v$ is in $\mathrm{m} / \mathrm{s}$.
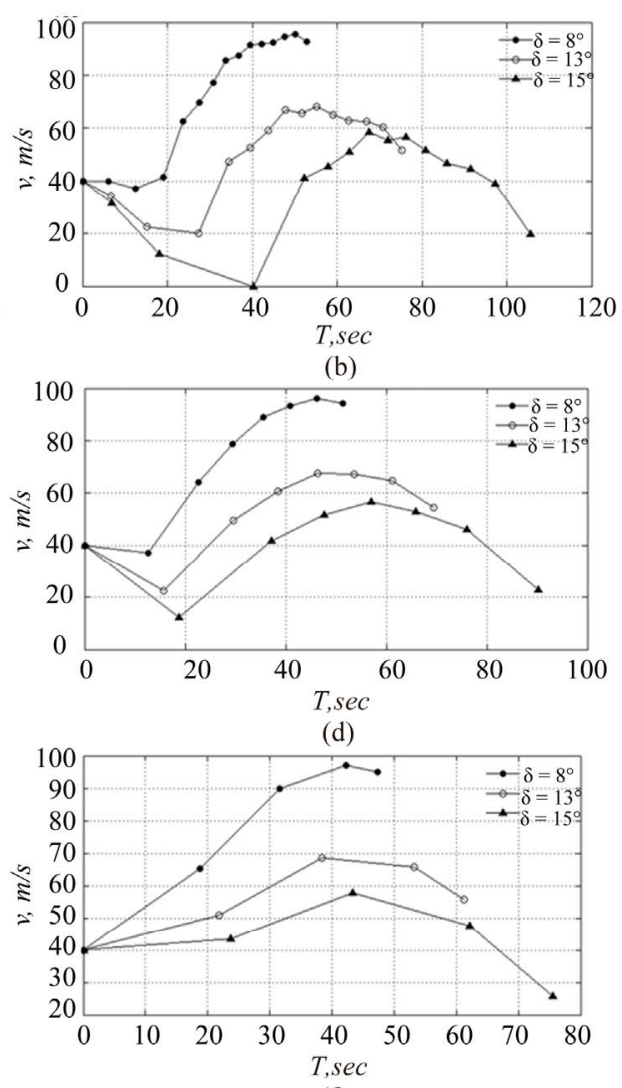

(f)

Figure 4. Velocity of the pyroclastic flow along the Tar river profile for the original (a,b), small (c,d) and moderate resolution (e, f): Velocity versus distance (left column) and velocity versus time (right column). 


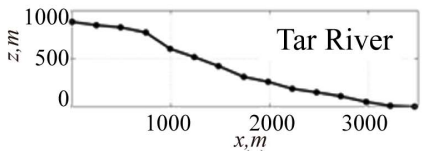

(a)

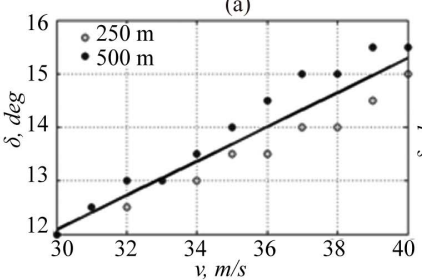

(e)
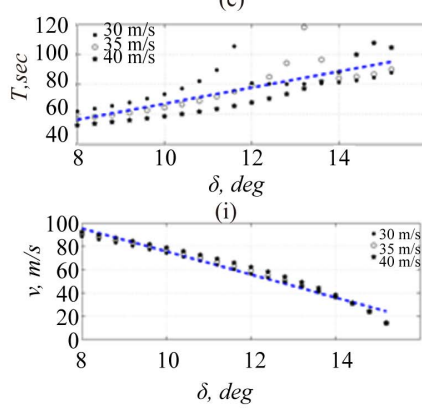

(m)

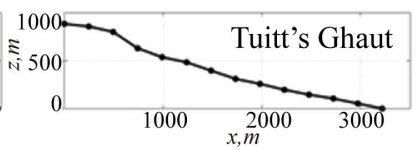

(b)

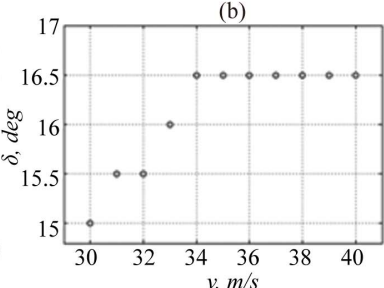

(f)

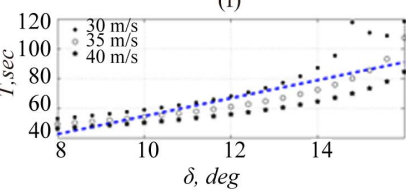

(g)

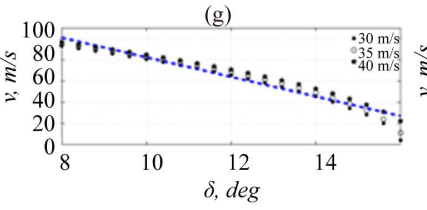

(n)
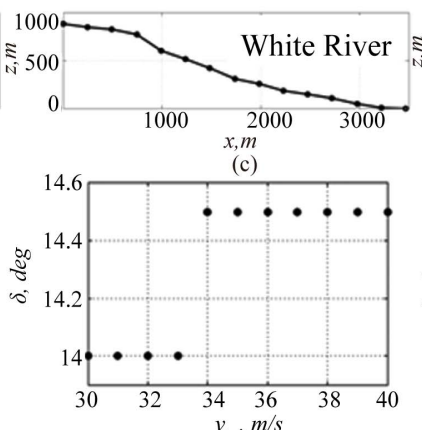

(g)

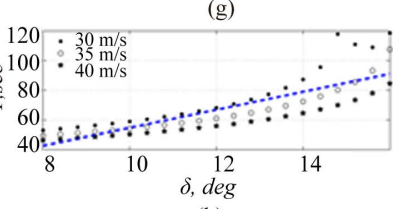

(k)

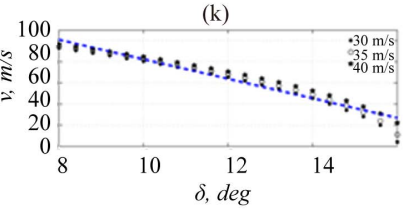

(o)

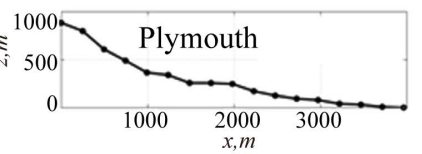

(d)

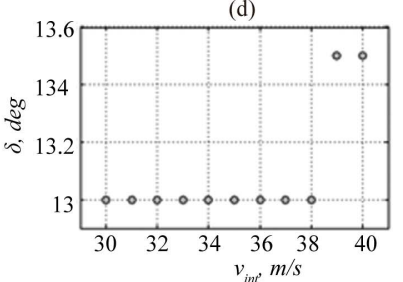

(h)

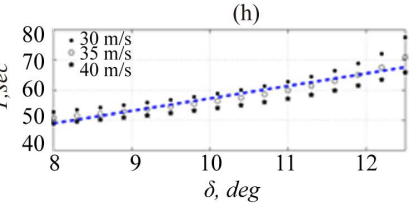

(1)

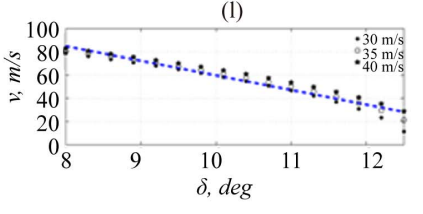

(p)

Figure 5. Parameters of the pyroclastic flow in likely directions: the original profile (a-d); the critical friction angle of the propagation (e-h); travel time (i-l); impact velocity (m-p).

\subsection{Tuitt's Ghaut Direction}

Since 1995 the northern side of the volcano has been strongly affected by the surge, by main and derivative pyroclastic flows [29]. Debris torrents occurred in Tuitt's Ghaut in mid-November, 2009 when a moderate flow was observed; followed by numerous torrents in the end of November. In December the runout distance of pyroclastic flows reached $2 \mathrm{~km}$ from lava dome; after several weeks of large pyroclastic flows, helicopter observations showed that the head of Tuitt's Ghaut was full of pyroclastic deposits [33].

Based on the topography data presented in [34], the splines of different resolution are examined, the original one is given in Figure 5(b). It is interesting to mention that Tuitt's Ghaut is located close to the Tar River profile described in the previous section. Both profiles have a characteristic feature that influence the propagation of the pyroclastic flow: a zone of the steep slope is clearly observed $500 \mathrm{~m}$ from the top. This peculiarity makes the pyroclastic flow decelerate. In general, the Tuitt's Ghaut profile is rather homogeneous, with average slope angle $15^{\circ}$.

The study of critical characteristics appears to be very conclusive, see Figure 5(f) where calculated data for the original resolution of $250 \mathrm{~m}$ is given; the same values are obtained for the moderate resolution of $500 \mathrm{~m}$. The critical angle varies from $15^{\circ}$ to $16.5^{\circ}$ being almost constant for the initial velocity more than $34 \mathrm{~m} / \mathrm{s}$.
Mean values of the significant parameters are studied using the same approach as described in the previous section. It takes about $50-100$ seconds to cover a distance of $3200 \mathrm{~m}$, Figure 5(j). It bears repeating that time alert up to $1-2$ minutes is rather short to claim the alarm. The deviation between values of the travel time obtained for different cases is rather big. The travel time can be approximated by a simple linear regression:

$$
T_{\text {Tuits Ghaut }}=6 \cdot \delta-6 \quad R=0.82 \text {, }
$$

where $T$ is in seconds, friction angle $\delta$ is in degrees.

According to calculations, the impact velocity varies from 30 to $100 \mathrm{~m} / \mathrm{s}$, Figure 5(n). Considering the fact that during the period of high volcanic activity in November-December 2009 no pyroclastic flow reached the sea in this direction, it would appear reasonable to suppose that either real basal friction angle is bigger that $16^{\circ}$ or initial velocity of the pyroclastic flow is less than $30 \mathrm{~m} / \mathrm{s}$. Deviation between obtained values of the impact velocity for different cases is rather insignificant, and a linear regression can be used to approximate this parameter,

$$
v_{\text {Tuits Ghaut }}=-9 \cdot \delta+175, \quad R=0.97,
$$

where entrance velocity $v$ is in $\mathrm{m} / \mathrm{s}$, friction angle $\delta$ is in degrees.

\subsection{White River Direction}

In December 1997 a debris avalanche and a pyroclastic 
flow with a volume of $55 \cdot 10^{6} \mathrm{~m}^{3}$ were produced in White River valley [29]; this lateral blast is associated with the tsunami inundated $80 \mathrm{~m}$ inland at the Old Road Bay $[7,8,35]$, see Figure 1; this event was actively studied $[7,24,36]$. This tsunami might have reached the neighbor island (Guadeloupe) situated about $50 \mathrm{~km}$ from Montserrat. Zahibo et al. [37] suggested that the eruption of Soufrière Hills Volcano represents a potential danger of distant tsunami. In October 2009 the pyroclastic flow deposits extended $3 \mathrm{~km}$ down the White River. In November - December 2009 small pyroclastic flows occurred in the White River valley. In November 2009 pyroclastic flows moved down Gingoes Ghaut (SSW from White River valley) to within $200 \mathrm{~m}$ of the sea [33].

Geographically, the White River profile is divided into 2 paths of different slope angle, the first one stretches for $500-700 \mathrm{~m}$ and is characterized by a big slope angle (up to $30^{\circ}$ ) that is followed by a steep path with a mean slope angle about $11^{\circ}$. The latter decelerates significantly the propagation of the pyroclastic flow [34], see Figure 5(c).

Computed critical characteristics of the propagation of the pyroclastic flow ( $250 \mathrm{~m}$ resolution) are presented in Figure 5(g). According to calculations, the pyroclastic flow does not stop and reaches the sea when splines of other resolutions are used. This peculiarity can be explained by the fact that there are no sudden changes of the slope angle and the pyroclastic flow is not decelerated.

For all profiles in the White River direction mean values of the travel time and the impact velocity are determined, Figure 5(k). The travel time can be approximated by a following linear regression

$$
T_{\text {White River }}=4 \cdot \delta+16, \quad R=0.91,
$$

where $T$ is in seconds, the friction angle $\delta$ is in degrees. The impact velocity is also examined, and it is shown that the impact velocity decreases considerably when the basal friction angle is slightly modified, Figure 5(o). A simple regression (14) is characterized by a high value of the coefficient of correlation $R$ :

$$
v_{\text {White River }}=-11 \cdot \delta+178, R=0.97,
$$

where $v$ is in $\mathrm{m} / \mathrm{s}$.

\subsection{Plymouth Direction}

A former capital of Montserrat, Plymouth was abandoned after the eruption of the Soufriere Hills eruption in 1997. In June 1997 pyroclastic debris entered the Belham Valley, when a portion of the surge cloud detached to travel westwards of Cork Hill [4], see Figure 1 for locations. Since then a partial dome collapse with pyroclastic flow activity has occurred once: on 8 January 2007 pyro- clastic density currents were observed in Gages Valley.

The original geographical profile in the direction of Plymouth [34] is given in Figure 5(d). It is characterized by a complicated geometry; it consists of several paths of different inclination. The first steep path that stretches for $1000 \mathrm{~m}$ is described by a big slope $\left(19^{\circ}-38^{\circ}\right)$, then another path begins $\left(6^{\circ}-18^{\circ}\right)$, after that a plain and extended zone is located. One more path is observed 2000 $\mathrm{m}$ from the volcano peak $\left(\alpha<17^{\circ}\right)$.

In Figure 5(h) critical characteristics of the propagation of the pyroclastic flow for the original resolution are presented; the same values are obtained for the resolution of $500 \mathrm{~m}$. For a wide range of the initial velocity $(30-38 \mathrm{~m} / \mathrm{s})$, the critical friction angle is the same $\left(13^{\circ}\right)$.

Let us discuss briefly peculiarities of the impact velocity and travel time, related with the geometry of the profile in the direction of Plymouth. The pyroclastic flow traverses $4000 \mathrm{~m}$, from the top of the volcano to the sea shore, in a short period of time (50 - 80 seconds), but calculated values have a wide scatter, Figure 5(I). As for the impact velocity, it depends significantly on the friction angle, Figure 5(p). Both parameters can be approximated by linear regressions:

$$
\begin{aligned}
T_{\text {Plymouth }}=4 \cdot \delta+16, & R=0.89, \\
v_{\text {Plymouth }}=-13 \cdot \delta+185, & R=0.97,
\end{aligned}
$$

\subsection{Discussion}

A series of calculations are produced to estimate characteristic parameters of the propagation of the pyroclastic flow during eruptions of the Soufrière Hills Volcano, Montserrat. In the framework of the solid model key-characteristics of the pyroclastic flow are calculated for likely directions; and these profiles are rather similar in terms of the length and the slope angle, Figure 6(a). The Tuitt's Ghaut and Tar River profiles situated close one to another, are characterized by a steep zone of top near volcano peak, and this characteristic feature influences the propagation of the pyroclastic flow (detailed description of this phenomenon is given in paragraph 3.1). As for the Plymouth and White River profiles oriented to the west, a zone of big slope angle is located near the peak of the volcano that makes the pyroclastic flow descend with acceleration. Another curios point to mention is that all profiles are similar over a distance of $2000 \mathrm{~m}$ from the volcano peak.

Critical parameters of the pyroclastic flow with the moderate initial velocity $(30 \mathrm{~m} / \mathrm{s}-40 \mathrm{~m} / \mathrm{s})$ calculated for original profiles are specially compared, Figure 6(b). For example, in the Tuitt's Ghaut direction, the pyroclastic flow stops when the friction exceeds $15^{\circ}-16^{\circ}$, such conclusion seems to be closely related with the mean 
value of the slope angle in this direction $\left(\alpha=15^{\circ}\right)$. In the Plymouth direction, the pyroclastic flow stops when the friction angle is equal to $13^{\circ}$ that exceeds the mean slope angle $\left(\alpha=12^{\circ}\right)$. In general, the critical friction angle differs slightly for various directions being in a range from $12^{\circ}$ (Tar River) to $16.5^{\circ}$ (Tuitt's Ghaut). The range of critical angles for all profiles is rather wide. In the Tuitt's Ghaut direction (homogeneous with average slope angle $\alpha=15^{\circ}$ ), the pyroclastic flow can propagate farther than in other directions (exactly what happened in October-November 2009).

Principal parameters of the pyroclastic flow are estimated for different profiles ( $250 \mathrm{~m}$ resolution) and moderate initial velocity $(30 \mathrm{~m} / \mathrm{s}-40 \mathrm{~m} / \mathrm{s})$, Figure 6(c)-(d). Although linear regressions are rather similar with the deviation of 15 - 20 seconds, the pyroclastic flow reaches the sea faster in case it propagates in the White River direction. It is notable that Heinrich et al. [24] who performed 3D simulation of the 1997 avalanche when pyroclastic flows were observed in White River valley, pointed out that the small friction angle $\left(13^{\circ}-15^{\circ}\right)$ gives the best agreement. It correlates with our results as the solid model approach demonstrates that torrents do not reach the sea in characteristic direction in case friction angle is greater than $16^{\circ}$.

Previously, the travel time of the pyroclastic flow was assumed to be 60 seconds by Heinrich et al. [36] who applied homogeneous fluid model to describe the motion of the pyroclastic flow in White River valley in December 1997. Later, Heinrich et al. [24] studied the same event considering the model of incompressible homogeneous fluid under the joint action of gravity and Coulomb friction and showed that the travel time attained 3 minutes that is close to our estimations. However, from the point of mitigation view, the time available to spread the alarm, is rather short. Earlier the potential danger of distant tsunami triggered by pyroclastic flow from the Soufrière Hills Volcano was discussed by [37]; recently, Bellotti et al. [38] studied the feasibility of Tsunami Early Warning Systems for small volcanic islands, and came to the conclusion that time available for detecting tsunamis and spreading the alarm is of the order of few minutes.

Another important parameter studied for all profiles is the impact velocity fitted by a linear regression, Figure 6(d). The biggest values of the impact velocity are achieved in case of the Tuitt's Ghaut's profile. In general, the impact velocities are rather important in terms of possible tsunami generation. Previously Heinrich et al. [36] obtained that the pyroclastic flow reached the sea in a minute with velocities of $80 \mathrm{~m} / \mathrm{s}$. That is close to our calculations obtained in the framework of the solid model in case of small friction $\left(9^{\circ}-10^{\circ}\right)$. Previously, Heinrich et al. [7]

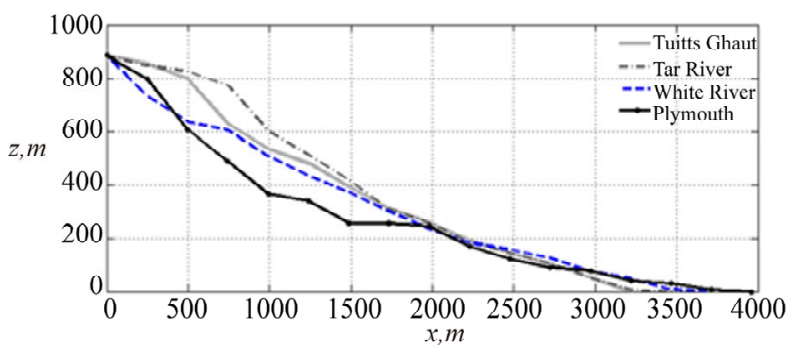

(a)

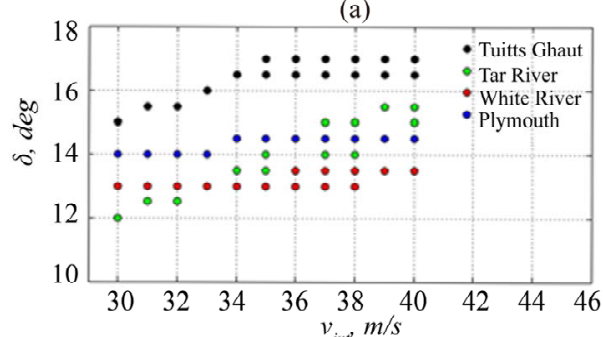

(b)

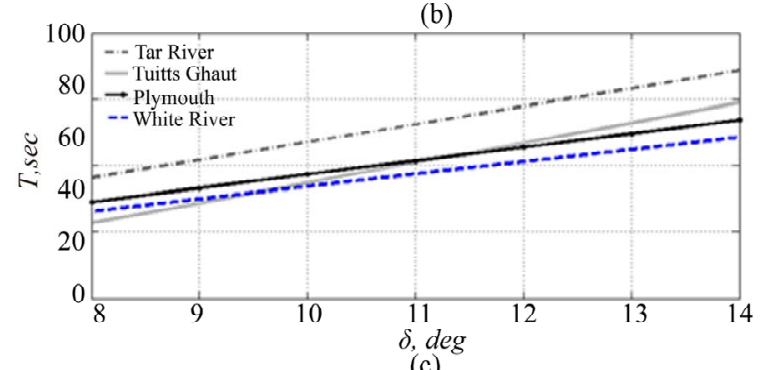

(c)

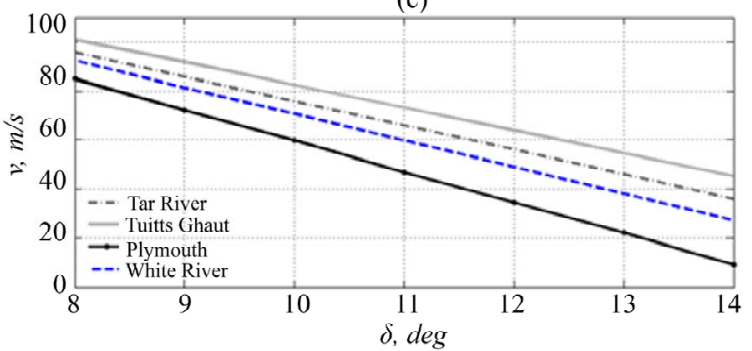

(d)

Figure 6. Calculated parameters of the pyroclastic flow in the likely directions: original profiles (a); the critical friction angle of the propagation (b); travel time (c); impact velocity (d).

studied tsunami simulation from Montserrat, and considered impact velocities from $25 \mathrm{~m} / \mathrm{s}$ to $55 \mathrm{~m} / \mathrm{s}$. The same values are obtained in the framework of our approach for large initial velocity of the dome collapse $(35 \mathrm{~m} / \mathrm{s}-40 \mathrm{~m} / \mathrm{s})$ and moderate values of the friction angle $\left(13^{\circ}-15^{\circ}\right)$.

Thus, main characteristic parameters of the pyroclastic flow associated with possible tsunami, are quite similar for different likely directions, except the critical basal friction angle that differs significantly from $12^{\circ}$ to $16.5^{\circ}$. This permits to give rough estimations of main characteristics required to analyze not only the propagation of the pyroclastic flow, but also tsunami generation.

In fact, the pyroclastic flow events associated with the small collapse of lava dome have been reported since 
October 2009, but only few of them reached the sea; and no tsunami warning was issued [33]. No data about the volume of pyroclastic flows is available but according to our calculations, the pyroclastic flow does not reach the sea when its initial velocity is less than $20 \mathrm{~m} / \mathrm{s}$ that correspond to collapse of dome $30 \mathrm{~m}$ height. So, theoretical predictions for small events are in agreement with observed data. At the present time due to continuous eruption of the Soufrière Hills Volcano, dome grows and thus the tsunami danger rises.

\section{Conclusions}

The application of the avalanche model, based on the solid block approach, is discussed here to describe the motion of the pyroclastic flow from the Soufrière Hills Volcano, Montserrat. Two parameters are determined to study the propagation of the pyroclastic flow: Coulomb friction and the initial velocity of the pyroclastic flow. The analysis of average characteristics of the pyroclastic flow is performed for different friction angles $\left(8^{\circ}-17^{\circ}\right)$, and moderate initial velocity of $30 \mathrm{~m} / \mathrm{s}-40 \mathrm{~m} / \mathrm{s}$. The theoretical model is applied to calculate parameters of the pyroclastic flow in the likely directions (Tar River, White River, Tuitt's Ghaut and Plymouth). Several resolutions of mountain profiles are used, and it is shown that results are sensitive to spline approximation and the use of the average slope angle leads to improper conclusions. At the same time, the original and slightly modified resolution $(250 \mathrm{~m}-500 \mathrm{~m})$ make possible to describe the observed descend of the pyroclastic flow. The spatial and temporal variations of the velocity in case of the large initial velocity are specially discussed for the Tar River profile. It is shown that the propagation of the pyroclastic flow is described rather fairly in the framework of the applied theoretical model when small profiles are used $(250 \mathrm{~m}$ and $500 \mathrm{~m}$ ), and the effect of topography (the steep zone) that decelerates the pyroclastic flow, is observed. For all likely directions, the critical friction angle is evaluated empirically from performed calculations for the small resolution; it varies significantly from $12^{\circ}$ to $16.5^{\circ}$ for different profiles. Two parameters of the pyroclastic flow are particularly discussed: the travel time and the impact velocity, these characteristics are important from the point of view of tsunami generation. It is shown that both parameters are approximated by similar linear regressions for all studied directions. Generally, the impact velocity hardly exceeds $100 \mathrm{~m} / \mathrm{s}$. What is more, the insignificant variation of the friction acts very much on the impact velocity of the pyroclastic flow. The travel time does not exceed 2 minutes; and time available to spread the alarm is rather short; furthermore, volcano eruptions can represent a potential danger of distant tsu- nami for coastal regions far from Montserrat Island that should be taken into consideration. Proposed estimations of the parameters of the pyroclastic flow in the framework of the solid model are useful for the rough and express evaluation of the characteristics of the debris avalanche.

\section{Acknowledgements}

Partial support from the grants: CPER (2007-2013), ANR project (Vitesss), RFBR (11-05-00216; 11-0597006) and State Contract $(02.740 .11 .0732)$ is gratefully acknowledged.

\section{References}

[1] S. R. Young, R. S. J. Sparks, W. P. Aspinall, L. L. Lynch, A. D. Miller, R. E. A. Robertson and J. B. Shepherd, "Overview of the Eruption of Soufrière Hills Volcano, Montserrat, July 181995 to December 1997," Geophysical Research Letters, Vol. 25, 1998, pp. 3389-3392. doi:10.1029/98GL01405

[2] R. A. Herd, M. Edmonds and V. A. Bass, "Catastrophic Lava Dome Failure at Soufrière Hills Volcano, Montserrat, 12-13 July 2003," Journal of Volcanology and Geothermal Research, Vol. 148, 2005, pp. 234-252. doi:10.1016/j.jvolgeores.2005.05.003

[3] S. A. Carn, R. B. Watts, G. Thompson and G. E Norton, "Anatomy of a Lava Dome Collapse: The 20 March 2000 Event at Soufrière Hills Volcano, Montserrat," Journal of Volcanology and Geothermal Research, Vol. 131, No. 3-4, 2004, pp. 241-264. doi:10.1016/S0377-0273(03)00364-0

[4] S. De Angelis, V. Bass, V. Hards and G. Ryan, "Seismic Characterization of Pyroclastic Flow Activity at Soufrière Hills Volcano, Montserrat, 8 January 2007," Natural Hazards and Earth System Sciences, Vol. 7, No. 4, 2007, pp. 467-472. doi:10.5194/nhess-7-467-2007

[5] Le Friant, E. J. Lock, M. B. Hart, G. Boudon, R. S. J. Sparks, M. J. Leng, C. W. Smart, J. C. Komorowski, C. Deplus and J. K. Fisher, "Late Pleistocene Tephrochronology of Marine Sediments Adjacent to Montserrat, Lesser Antilles Volcanic Arc," Journal of the Geological Society, Vol. 165, No. 1, 2008, pp. 279-289. doi:10.1144/0016-76492007-019

[6] M. Ripepe, S. De Angelis, G. Lacanna, P. Poggi, C. Williams, E. Marchetti, D. Delle Donne and G. Ulivieri, "Tracking Pyroclastic Flows at Soufrière Hills Volcano," Eos, Vol. 90, No. 27, 2009, pp. 229-230. doi:10.1029/2009EO270001

[7] P. Heinrich, A. Mangeney, S. Guibourg and R. Roche, "Simulation of Water Waves Generated by Potential Debris Avalanche in Montserrat, Lesser Antilles," Geophysical Research Letters, Vol. 25, No. 18, 1998, pp. 3697-3700. doi:10.1029/98GL01407

[8] G. Pararas-Carayannis, "Volcanic Tsunami Generating Source Mechanisms in the Eastern Caribbean Region," 
Science of Tsunami Hazards, Vol. 22, No. 2, 2004, pp. 74-114.

[9] E. Pelinovsky, N. Zahibo, P. Dunkley, M. Edmonds, R. Herd, T. Talipova, A. Kozelkov, I. Nikolkina, "Tsunami Generated by the Volcano Eruption on July 12-13, 2003 at Montserrat, Lesser Antilles," Science Tsunami Hazards, Vol. 22, No. 1, 2004, pp. 44-57.

[10] N. Zahibo, "Deshaies, Guadeloupe Tsunami, 20 May 2006, Montserrat, Lesser Antilles, Soufriere volcano tsunami," Tsunami Newsletter, Vol. 38, No. 2, 2006. http://ioc3.unesco.org/itic/files/2006_May-June_screen. pdf (last access: November, 2010).

[11] National Geophysical Data Center, NGDC, 2010. http://www.ngdc.noaa.gov/hazard/tsu.shtml

[12] A. Mangeney, P. Heinrich and R. Roche, "Analytical Solution for Testing Debris Avalanche Numerical Models," Pure and Applied Geophysics, Vol. 157, No. 6-8, 2000a, pp. 1081-1096. doi:10.1007/s000240050018

[13] M. Arattano and L. Franzi, "On the Evaluation of Debris Flows Dynamics by Means of Mathematical Models," Natural Hazards and Earth System Sciences, Vol. 3, No. 6, 2003, pp. 539-544. doi:10.5194/nhess-3-539-2003

[14] I. V. Fine, A. B. Rabinovich, R. E. Thomson and E. A. Kulikov, "Numerical Modeling of Tsunami Generation by Submarine and Subaerial Landslides," Kluwer Academic Publishers, Berlin, 2003, pp. 69-88.

[15] I. Didenkulova, I. Nikolkina, E. Pelinovsky and N. Zahibo, "Tsunami Waves Generated by Submarine Landslides of Variable Volume: Analytical Solutions for a Basin of Variable Depth," Natural Hazards and Earth System Sciences, Vol. 10, No. 11, 2010, pp. 2407-2419. doi:10.5194/nhess-10-2407-2010

[16] I. F. Nikolkina, E. N. Pelinovsky and T. G. Talipova, "Nonlinear Dynamics of Gravity Flows in Sloping Channels," Doklady Earth Sciences, Vol. 432, No. 2, 2010, pp. 812-815. doi:10.1134/S1028334X1006022X

[17] I. F. Nikolkina, E. N. Pelinovsky, T. G. Talipova, N. Zahibo, "Solid and Fluid Models of Avalanche Dynamics," Natural Hazards: Studying, Monitoring and Forecasting, 2011, pp. 19-29.

[18] N. Zahibo, E. Pelinovsky, T. Talipova and I. Nikolkina, "Savage-Hutter Model for Avalanche Dynamics in Inclined Channels: Analytical Solutions," Journal of Geophysical Research, Vol. 115, 2010, p. B03402, doi:10.1029/2009JB006515

[19] C. B. Harbitz, "Model Simulations of Tsunamis Generated by the Storegga Slides," Marine Geology, Vol. 105, No. 1-4, 1992, pp. 1-21. doi:10.1016/0025-3227(92)90178-K

[20] E. Pelinovsky and A. Poplavsky, "Simplified Model of Tsunami Generation by Submarine Landslides," Physics and Chemistry of the Earth, Vol. 21, No. 12, 1996, pp. 13-17. doi:10.1016/S0079-1946(97)00003-7

[21] S. Tinti, E. Bortolucci and C. Chiavettieri, "Tsunami Excitation by Submarine Slides in Shallow-Water Approximation," Pure and Applied Geophysics, Vol. 158, No. 4, 2001, pp. 759-797. doi:10.1007/PL00001203
[22] P. Watts, "Tsunami Features of Solid Block Underwater Landslides," Journal of the Waterway Port Coastal and Ocean Division-ASCE, Vol. 126, No. 3, 2000, pp. 144-152. doi:10.1061/(ASCE)0733-950X(2000)126:3(144)

[23] P. Heinrich, S. Guibourg, A. Mangeney and R. Roche, "Numerical Modeling of a Landslide-Generated Tsunami Following a Potential Explosion of the Montserrat Volcano," Physics and Chemistry of the Earth (A), Vol. 24, No. 2, 1999, pp. 163-168. doi:10.1016/S1464-1895(99)00013-7

[24] P. Heinrich, G. Boudon, J.-C. Komorowski, R. S. J. Sparks, R. Herd and B. Voight, "Numerical simulation of the December 1997 Debris Avalanche in Montserrat," Geophysical Research Letters, Vol. 28, No. 13, 2001, pp. 2529-2532. doi:10.1029/2001GL012968

[25] A. Mangeney, Ph. Heinrich, R. Rachel, G. Boudon and J. L. Chemin, "Modeling of Debris Avalanche and Generated Water Waves: Application to Real and Potential Events in Montserrat," Physics and Chemistry of the Earth (A), Vol. 25, No. 9-11, 2000b, pp. 741-745. doi:10.1016/S1464-1895(00)00115-0

[26] R. I. Perla, T. T. Cheng and D. M. McClung, "A TwoParameter Model of Snow Avalanche Motion," Journal of Glaciology, Vol. 26, No. 94, 1980, pp. 197-207.

[27] P. D. Cole, E. S. Calder, R. S. J. Sparks, A. B. Clarke, T. H. Druitt, S. R. Young, R. A. Herd, C. L. Harford and G. E. Norton, "Deposits from Dome-Collapse and Fountain-Collapse Pyroclastic Flows at Soufrière Hills Volcano, Montserrat," In: T. H. Druitt and B. P. Kokelaar, Eds., The Eruption of Soufrière Hills Volcano, Montserrat, from 1995 to 1999, Geological Society of London Memoirs, Vol. 21, 2002, pp. 231-262.

[28] E. S. Calder, R. Luckett, R. S. J. Sparks and B. Voight, "Mechanisms of Lava Dome Instability and Generation of Rock-Falls and Pyroclastic Flows at Soufrière Hills Volcano, Montserrat," Geological Society of London Memoir, Vol. 21, 2002, pp. 173-190.

[29] E. S. Calder, P. D. Cole, W. B. Dade, T. H. Druitt, R. P. Hoblitt, H. E. Huppert, L. Ritchie, R. S. J. Sparks and S. R. Young, "Mobility of Pyroclastic Flows and Surges at the Soufrière Hills Volcano, Montserrat," Geophysical Research Letters, Vol. 26, No. 5, 1999, pp. 537-540. doi:10.1029/1999GL900051

[30] Le Friant, Ph. Heinrich, Ch. Deplus and G. Boudon, "Numerical Simulation of the Last Flank-Collapse Event of Montagne Pelée, Martinique, Lesser Antilles," Geophysical Research Letters, Vol. 30, No. 2, 2003, pp. 1-6.doi: 10.1029/2002GL015903

[31] A. Le Friant, G. Boudon, J.-Ch. Komorowski, Ch. Deplus, "L'île de la Dominique, à l'origine des avalanches de débris les plus volumineuses de l'arc des Petites Antilles," Comptes Rendus Geoscience, Vol. 334, No. 4, 2002, pp. 235-243. doi:10.1016/S1631-0713(02)01742-X

[32] C. Deplus, A. Le Friant, G. Boudon, J.-C. Komorowski, B. Villemant, C. Harford, J. Ségoufin and J.-L. Cheminée, "Submarine Evidence for Large-Scale Debris Avalanches in the Lesser Antilles Arc," Earth and Planetary Science 
Letters, Vol. 192, No. 2, 2001, pp. 145-157. doi:10.1016/S0012-821X(01)00444-7

[33] Montserrat Volcano Observatory, MVO, 2010. http://www.mvo.ms/

[34] The National Map of Seamless Server, NMSS, 2010. http://seamless.usgs.gov

[35] K. F. O’Loughlin and J. F. Lander, "Caribbean Tsunamis, a 500-Year History from 1498-1998," Kluwer Academic Publishers, Dordrecht/Boston/London, Netherlands, 2003.

[36] P. Heinrich, R. Roche, A. Mangeney and G. Boudon, "Modéliser un raz de marééé créé par un Volcano," LaRecherche, Vol. 318, 1999, pp. 66-71.
[37] N. Zahibo, E. Pelinovsky, A. Kurkin, I. Nikolkina, "Tsunami hazard for the French West Indies, Lesser Antilles," in" R. R. Krishnamurthy, B. C. Glavovic, A. Kannen, D. R. Green, A. L. Ramanathan, Z. Han, S. Tinti and T. Agardy, Eds., Integrated Coastal Zone ManagementThe Global Challenge, Research Publishing Services, Singapore, 2008, pp. 517-535.

[38] G. Bellotti, M. D. Risio and P. De Girolamo, "Feasibility of Tsunami Early Warning Systems for Small Volcanic Islands," Natural Hazards and Earth System Sciences, Vol. 9, No. 6, 2009, pp. 1911-1919. doi:10.5194/nhess-9-1911-2009 